\title{
Prevalence and Risk Factors of Abuse against Married Women in Eastern Saudi Arabia
}

Abdulellah Bohlaiga, Bader Al-Kakhli, Hassan Al-Mattar, Ibrahim Al-Bahrani, Kawther Al-Lowaim, Mohammed Al-Baqshi, Norah Al-Harthi, Rayan Al-Harbi, Sara Al-Moumen, Zahra Al-Hammad, Zahraa Al-Nasser and Faisal Alnasir ${ }^{*}$

Department of Family \& Community Medicine, Arabian Gulf University, Bahrain

"Corresponding author: Faisal Alnasir, Chairman, Department of Family \& Community Medicine College of Medicine and Medical Sciences, Arabian Gulf University, Bahrain, P O Box 26671, Tel: 00973 39464048; E-mail: faisal@agu.edu.bh

Rec date: Jan 20, 2014, Acc date: Feb 25, 2014, Pub date: Mar 01, 2014

Copyright: (c) 2014 Alnasir F, et al. This is an open-access article distributed under the terms of the Creative Commons Attribution License, which permits unrestricted use, distribution, and reproduction in any medium, provided the original author and source are credited.

\begin{abstract}
Background: Domestic abuse against a female is considered an anomalous deportment; however it is still an obnubilated quandary. Its prevalence rate is very high reaching up to $59 \%$ in certain communities. This study was done with the main objective of ascertaining the rate of women abuse in both Al-Dammam and $\mathrm{Al}-\mathrm{Ahsa}$ cities of Saudi Arabia and to explore the associated risk factors to it.
\end{abstract}

Materials and methods: A cross-sectional study was conducted on a convenient sample of 348 married Saudi women aged between 18 and 50 years, who have one child or more and live in the designated cities. The data were amassed by betokens of a pre-designed questionnaire.

Results: The prevalence of women abuse was found to be around $19 \%$, but reached to $33 \%$ when added to it the response of women to the abuse cognate questions. The highest rate was among women aged 40 years and older. The most mundane type of abuse was that of multiple types that accounted to $49 \%$ (which included verbal, physical and others). Vituperation accounted for 35.8\% and physical, emotional, and psychological accounted for $7.5 \%$ each. Abuse was higher among lower educated couples and in families with poor economic status. Only a moiety of the abused women sought help, and most did so from their families (71\%) and friends (17.8). Very few reported to the police.

Conclusion: The prevalence of abuse against women is underestimated, as many women did not admit frankly being abused while they did answer abuse cognate questions. Since this type of violence affects the stability of the family and the well-being of the victim, it is recommended to establish utilize multi disciplinary programs aiming at raising the cognizance level of the society against this eccentric demeanor. Educating current and future couples and opportune training of health care providers are very efficacious implements in early discovery and revelation of assistance to the abused female.

Keywords: Women abuse; Prevalence; Verbal; Physical; Psychological; Risk factors

\section{Introduction}

Intimate partner violence (IPV) is an earnest and obnubilated or underestimated quandary that affects many women all around the world. There are many definition assigned to that term however the Center of Disease Control has ascribed it as "the physical, sexual, or psychological harm induced by a current or former partner or spouse" [1]. Moreover violence against women has been defined by the United Nations as "any act of gender-based violence that results in, or is likely to result in, physical, sexual or mental harm or suffering to women" [2]. Therefore, domestic abuse is an anomalous deportment in any marital relationship. It is customarily committed by one partner against the other. Gender-predicated violence against women is a malefaction and is an infringement to the human rights that occurs, often perpetually, during the lives of many women around the world, especially in the developing countries. Albeit the forms of violence experienced may differ depending on sundry cultural or socioeconomic factors, there are aspects of that violence that are universal. Such forms could be physical, sexual, emotional, psychological, financial, spiritual, cultural, and revilement or neglect could result in astringent harm to the victim's salubrity. Violence against women occurs in all societies despite age, religion, edifying level, culture, marital status, economic status, and residential differences. Abuse is reported to occur even to pregnant women and its prevalence can reach up to $65 \%$ [3]. Such women have incremented risk of despondence and post-traumatic stress disorder, which increase likelihood of neonatal complications and affect their breastfeeding abilities [4,5].

Albeit, female abuse is a worldwide phenomenon yet it is still an obnubilated quandary that requires to be investigated. However, studies about violence against women are circumscribed in the Arab world, which could be cognate to taboo and cultural believes. The few studies that were conducted showed that women abused by their husbands are a consequential convivial quandary in this component of the world that leads to physical and psychological health impact on the victim. Population-predicated surveys conducted in multiple countries during 2011 have shown that the prevalence of domestic abuse ranges between 15\% to 71\% [2]. A 2011 study from Saudi Arabia found that the prevalence of lifetime domestic violence in Al-Ahsa of the eastern 
province was $39.3 \%$, while for mental violence it was $35.9 \%, 17.9 \%$ for physical, and $6.9 \%$ for sexual violence [6].

In Egypt $60 \%$ of rural women were exposed to domestic violence in their espousement life, while the incidence of violence among urban women was $41 \%$ [7]. Gender-predicated violence in developing countries could be mainly due to the lack of equipollence between men and women in certain societies. It frequently takes place at home and within the family circle. Societal tolerance for gender-predicated violence and the privacy of the act of violence when it takes place within the home can make it invisible or arduous to detect leading to under estimation of its prevalence. Risk factors for abuse are many but the most paramount are; sizably voluminous family size, divorce or disseverment, low inculcative level of both couples, husband's alcohol imbibing, drug abuse, and smoking habit [8]. Moreover, women with physical disabilities are more prone to being abused [9].

Few men who are involved in domestic violence have sometimes vigorous proclivity to justify their act [10]. Moreover, it was reported that some women who are adolescent, poor, unemployed, and have poor edification, sometimes do accept being abused by their spouse $[11,12]$.

The main aim of this study was to ascertain the prevalence of abuse in Al-Dammam and Al-Ahsa of Saudi Arabia (KSA) against espoused women and to explore the peril factors associated with abuse.

\section{Material and Methods}

A cross sectional study on a convenient sample of 348 women aged between 18 and 50 years was carried out during 2013. The sample populations were national, espoused women with one child or more and live in Al-Dammam and Al-Ahsa in the eastern province of the Kingdom of Saudi Arabia. They were recruited from a few randomly selected government health centers and hospitals in both those areas. All women who visited those facilities during a fixed time period and who fit the inclusion criteria were included in the study after obtaining their permission.

Data accumulation was made utilizing a self-administered questionnaire in which its variables were tenacious predicated on the information obtained from sundry reviewed literature. The questionnaire was indited in Arabic language and after many error and tribulation including testing it by a pilot study, its sentences and words was rephrased in a simple facile understandable Arabic language. The pilot study which was done on 20 espoused women, aged between 18 to 50 years old was aimed also to test the validity and pellucidity of the questionnaire and to explore its facile filling and the time taken by each person for consummating it. Ethical issues were considered via obtaining sanctions for the conduction of the study from both FAMCO department and the Research and Ethical Committee at the Arabian Gulf University. Moreover permission was granted from the specified health facilities and the studied women. Data were analyzed utilizing SPSS statistical package (version 20). P value level $<0.05$ was considered consequential.

\section{Results}

Out of the total 348 women, 156(45\%) and 192(55\%) were recruited from Al-Dammam and Al-Ahsa respectively. The demographic characteristics of the women are as shown in Table 1.

Education was divided into three categories; (i) uneducated for those who are illiterate, (ii) low education, those who have twelve and less years of school education and (iii) high education for those who had university educations. Very few women were uneducated while most were employed. The majority had more than one child $(81 \%)$ and $62 \%$ of the couples were not proximately cognate. The majority of their spouses were edified of whom $56 \%$ were having lower edification and $44 \%$ had high education level (university degree) and employed. Moreover, the majority was employed, sizably voluminous numbers of them were smokers (41\%), and few were alcohol imbiber (2\%). Seven percent (22) of the spouses were in fact being abused during their childhood (Table 2).

No efforts were made to assign a certain figure for the caliber of economic status. On the contrary it was divided into three categories (good, average and poor) according to what the women perceived their status is, as a fine-tuned amount of income could be misleading in categorizing people in this component of the world. The majority, [65\% (221)] thought that their economic status is good, 31\% (107) verbalized average while only $4 \%$ (14) thought that they have poor economic status. Information related to abuse: Table 3.

\begin{tabular}{|l|l|l|}
\hline \multirow{5}{*}{ Education } & Responses & Frequency/Percent \\
\hline \multirow{5}{*}{ Women job } & Uneducated & $2(0.6 \%)$ \\
\cline { 2 - 3 } & Lower education & $157(45.5 \%)$ \\
\cline { 2 - 3 } & Higher education & $186(53.9 \%)$ \\
\cline { 2 - 3 } & Total & $345(100 \%)$ \\
\hline \multirow{5}{*}{ Living place } & Housewives & $166(49.8 \%)$ \\
\cline { 2 - 3 } & Student & $26(7.8 \%)$ \\
\cline { 2 - 3 } & Retired & $8(2.4 \%)$ \\
\cline { 2 - 3 } & Employed & $133(39.9 \%)$ \\
\cline { 2 - 3 } & Total & 333 \\
\hline & Owned & $168(49.1 \%)$ \\
\cline { 2 - 3 } & Rented & $120(35.1 \%)$ \\
\hline
\end{tabular}


Citation: Bohlaiga A, Al-Kakhli B, Al-Mattar H, Al-Bahrani I, Al-Lowaim K et al. (2014) Prevalence and Risk Factors of Abuse against Married

Page 3 of 6

\begin{tabular}{|l|l|l|}
\hline \multirow{5}{*}{ No. of Children } & With Husbands' Parents & $53(15.5 \%)$ \\
\cline { 2 - 3 } & Other & $1(0.3 \%)$ \\
\cline { 2 - 3 } & Total & 342 \\
\hline \multirow{5}{*}{ Consanguinity } & 1 & $62(19.2 \%)$ \\
\cline { 2 - 3 } & $2-5$ & $230(71.2 \%)$ \\
\cline { 2 - 3 } & $>5$ & $31(9.6 \%)$ \\
\cline { 2 - 3 } & Total & $323(100 \%)$ \\
\hline & Yes & $122(38 \%)$ \\
\cline { 2 - 3 } & No & $202(62 \%)$ \\
\cline { 2 - 3 } & Total & 324 \\
\hline
\end{tabular}

Table 1: Demographic characteristics

\begin{tabular}{|c|c|c|c|c|c|c|}
\hline & Responses & Frequency/ & \multirow{5}{*}{\multicolumn{2}{|c|}{$\begin{array}{l}\text { Type of } \\
\text { abuse } \\
\text { suffered }\end{array}$}} & Physical & $8(36 \%)$ \\
\hline & & Percentage & & & Emotional & $5(23 \%)$ \\
\hline \multirow[t]{5}{*}{ Education } & \multirow{2}{*}{$\begin{array}{l}\text { Uneducated } \\
\text { (illiterate) }\end{array}$} & \multirow[t]{2}{*}{$7(2.1 \%)$} & & & Sexual & $2(9 \%)$ \\
\hline & & & & & Neglect & $7(32 \%)$ \\
\hline & \multirow{2}{*}{$\begin{array}{l}\text { Educated } \\
\text { (any level of formal } \\
\text { education) }\end{array}$} & \multirow{2}{*}{$332(97.9 \%)$} & & & Total & 22 \\
\hline & & & \multirow{4}{*}{\multicolumn{2}{|c|}{$\begin{array}{l}\text { Loss of Job } \\
\text { during } \\
\text { marriage }\end{array}$}} & Yes & $44(14 \%)$ \\
\hline & Total & 339 & & & No & 264 (84\%) \\
\hline \multirow[t]{3}{*}{ Employment } & Employed & $287(86.7 \%)$ & & & Do not know & $6(2 \%)$ \\
\hline & Unemployed & $44(13.3 \%)$ & & & Total & 314 \\
\hline & Total & 331 & \multirow{2}{*}{\multicolumn{4}{|c|}{ Table 2: Demographic and various factors related to the husbands }} \\
\hline \multirow[t]{4}{*}{ Smoking } & Yes & $134(41 \%)$ & & & & \\
\hline & No & $189(58 \%)$ & & Respons & & Frequency/ Percent \\
\hline & Do not know & $39(1 \%)$ & \multirow[t]{5}{*}{ Being Abused } & Yes & & $62(18.7 \%)$ \\
\hline & Total & 326 & & No & & $265(79.8 \%)$ \\
\hline \multirow[t]{4}{*}{ Alcohol drinking } & Yes & $8(2 \%)$ & & Do not kr & & $5(1.5 \%)$ \\
\hline & No & $302(94 \%)$ & & Missing & & 16 \\
\hline & Do not know & $12(4 \%)$ & & Total & & 348 \\
\hline & Total & 322 & \multirow[t]{5}{*}{ Type of abuse } & Physical & & $5(7.5 \%)$ \\
\hline \multirow[t]{4}{*}{ Disturbed psychological } & Yes & $21(6 \%)$ & & Verbal & & $24(35.8 \%)$ \\
\hline & No & $295(90 \%)$ & & Emotiona & sychological & $5(7.5 \%)$ \\
\hline & Do not know & $11(3 \%)$ & & More tha & & $33(49.2 \%)$ \\
\hline & Total & 327 & & Total & & $67^{*}$ \\
\hline \multirow{4}{*}{$\begin{array}{l}\text { Was abused during } \\
\text { his childhood period }\end{array}$} & Yes & $22(7 \%)$ & \multirow{4}{*}{$\begin{array}{l}\text { Frequency of } \\
\text { Abuse }\end{array}$} & Very ofte & & $13(11.3 \%)$ \\
\hline & No & $210(66 \%)$ & & Sometim & & $33(28.7 \%)$ \\
\hline & Do not know & $87(27 \%)$ & & Occasior & & $69(60 \%)$ \\
\hline & Total & 319 & & Total & & $115^{* *}$ \\
\hline
\end{tabular}


Page 4 of 6

\begin{tabular}{|c|c|c|}
\hline \multirow[t]{4}{*}{ Tool of abuse } & Weapon & $2(5.9 \%)$ \\
\hline & Hands & $25(73.5 \%)$ \\
\hline & Others & 7 (20.6\%) \\
\hline & Total & 34 \\
\hline \multirow{4}{*}{$\begin{array}{l}\text { Abuse during } \\
\text { pregnancy }\end{array}$} & Yes & $26(36 \%)$ \\
\hline & No & $25(34 \%)$ \\
\hline & I do not know & $22(30 \%)$ \\
\hline & Total & $73^{* *}$ \\
\hline \multirow{3}{*}{$\begin{array}{l}\text { Whether } \\
\text { sought } \\
\text { help or not }\end{array}$} & Yes & $38(50 \%)$ \\
\hline & No & $38(50 \%)$ \\
\hline & Total & $76^{* *}$ \\
\hline \multirow{5}{*}{$\begin{array}{l}\text { Place of help } \\
\text { seeking }\end{array}$} & Family & $32(71.1 \%)$ \\
\hline & Friends & $8(17.8 \%)$ \\
\hline & Police & $3(6.7 \%)$ \\
\hline & Domestic violence organization & $2(4.4 \%)$ \\
\hline & Total & $45^{*}$ \\
\hline \multirow{4}{*}{$\begin{array}{l}\text { Is abuse } \\
\text { related } \\
\text { to husband's } \\
\text { job loss }\end{array}$} & Yes & $18(27 \%)$ \\
\hline & No & $43(64 \%)$ \\
\hline & Do not know & $6(9 \%)$ \\
\hline & Total & $67^{* *}$ \\
\hline
\end{tabular}

the authors did not endeavor to designate the number of abuse occasions, but was left to the abused women to categorize their abuse frequency according to their judgment. Table 4 shows all of the sample population's opinion about abuse.

\begin{tabular}{|c|c|c|}
\hline & Responses & Frequency/ Percentage \\
\hline \multirow{4}{*}{$\begin{array}{l}\text { Do husbands } \\
\text { have the right } \\
\text { to abuse women }\end{array}$} & Yes & $11(4 \%)$ \\
\hline & Do not know & $12(4 \%)$ \\
\hline & No & $250(92 \%)$ \\
\hline & Total & 273 \\
\hline \multirow{3}{*}{$\begin{array}{l}\text { Abuse } \\
\text { affect daily activity }\end{array}$} & Yes & $180(84.5 \%)$ \\
\hline & No & $33(15.5 \%)$ \\
\hline & Total & 213 \\
\hline \multirow{3}{*}{$\begin{array}{l}\text { Women's } \\
\text { activity outside home }\end{array}$} & Yes & $91(28 \%)$ \\
\hline & No & $233(72 \%)$ \\
\hline & Total & 324 \\
\hline \multirow{3}{*}{$\begin{array}{l}\text { History of } \\
\text { divorce }\end{array}$} & Yes & $29(9 \%)$ \\
\hline & No & $301(91 \%)$ \\
\hline & Total & 330 \\
\hline
\end{tabular}

Table 4: Response of the entire population sample to questions related to factors that are related to abuse

When they were asked to state what the act of abuse from spouse is denoted to them and whether it was acceptable, albeit the majority (92\%) were against it, $8 \%$ of the populations were either accepting abuse or have no abnegation to it. Many women, 85\% (180) thought that abuse would affect the women's daily life and activity however $16 \%$ (33) did not cerebrate so.

In additament, abuse was found to be significantly more mundane among spouses who are: Table 5 . the number of women who responded to the sets of questions, which were cognate to abuse has kept on transmuting from one question to the other, even in few it was higher from the total number of women who corroborated being abused. For example, 115 responded to the third question in sequence about the frequency of abuse making the authentic figure for the prevalence of abuse reaching to $33.1 \%$. This finding could be explicated by the fact that due to the taboo and the sensitivity issue of this subject some women did not initially admit frankly that they were abuse victims but later responded to the abuse cognate questions (Table 3). The abused women were asked about the method of violence used against them; most mundane type (49.3\%) was abuse by more than one type of methods (that included physical, verbal and psychological) while the most prevalent implement utilized in physical abuse were the hands (73.5\%). And virtually $30 \%$ of the women verbalized that their unemployed husbands abused them. One third of the women $(36 \%)$ were abused even during pregnancy. Only around a moiety of the women have sought avail to pacify the violence against them, of whom the majority (70\%) sought family support while surprisingly for such community, 7\% has contacted the police.

Out of the total women admitted being abused, $11 \%$ (13) were always being abused, 29\% (33) were sometimes being abused and $60 \%$ (69) were abused occasionally. It is consequential to denote here that

\begin{tabular}{|l|l|l|l|}
\hline Factors & Responses & Abused & P value \\
\hline \multirow{2}{*}{$\begin{array}{l}\text { Spouse } \\
\text { employment }\end{array}$} & Unemployed & $33 \%$ & $<0.043^{* *}$ \\
\cline { 2 - 4 } & Employed & $17 \%$ & \\
\hline \multirow{2}{*}{$\begin{array}{l}\text { Spouse } \\
\text { education }\end{array}$} & Lower education & $26 \%$ & $<0.002^{* *}$ \\
\cline { 2 - 4 } & Higher education & $9 \%$ & \\
\hline Consanguinity & Yes & $17 \%$ & $<0.454^{*}$ \\
\cline { 2 - 4 } & No & $21 \%$ & \\
\hline \multirow{2}{*}{ Spouse smoking } & Yes & $24 \%$ & $<0.422^{*}$ \\
\cline { 2 - 4 } & No & $16 \%$ & \\
\hline \multirow{2}{*}{$\begin{array}{l}\text { Spouse alcohol } \\
\text { drinking }\end{array}$} & Yes & $50 \%$ & $<0.001^{* *}$ \\
\cline { 2 - 4 } & No & $16 \%$ & \\
\hline \multirow{2}{*}{$\begin{array}{l}\text { Spouse loss of } \\
\text { job during marriage }\end{array}$} & Yes & $42 \%$ & $<0.003^{* *}$ \\
\cline { 2 - 4 } & No & $16 \%$ & \\
\hline
\end{tabular}




\begin{tabular}{|l|l|l|l|}
\hline \multirow{2}{*}{ Women's age } & $<40$ years & $16 \%$ & $<0.028^{* *}$ \\
\cline { 2 - 4 } & $>40$ years & $38 \%$ & \\
\hline $\begin{array}{l}\text { Women's } \\
\text { employment }\end{array}$ & Unemployed & $18 \%$ & $<0.590^{*}$ \\
\cline { 2 - 4 } & Employed & $20 \%$ & \\
\hline $\begin{array}{l}\text { Education of the } \\
\text { women }\end{array}$ & Lower education & $24.5 \%$ & $<0.139^{*}$ \\
\cline { 2 - 4 } & Higher education & $14 \%$ & \\
\hline \multirow{2}{*}{$\begin{array}{l}\text { Number } \\
\text { of } \\
\text { children }\end{array}$} & One child & $10 \%$ & \\
\cline { 2 - 4 } & $2-5$ & $20 \%$ & $<0.036^{* *}$ \\
\cline { 2 - 4 } & More than 5 & $29 \%$ & \\
\hline \multirow{2}{*}{$\begin{array}{l}\text { Place of living } \\
\text { Own / rented }\end{array}$} & $21 \%$ & $<0.271^{*}$ \\
\cline { 2 - 4 } & With the family & $10 \%$ & \\
\hline \multirow{2}{*}{$\begin{array}{l}\text { Women's } \\
\text { history of divorce }\end{array}$} & Yes & $52 \%$ & $<0.001^{* *}$ \\
\cline { 2 - 4 } & No & $16 \%$ & \\
\hline \multirow{2}{*}{$\begin{array}{l}\text { Women's activity } \\
\text { outside home }\end{array}$} & Yes & $20 \%$ & $<0.265^{*}$ \\
\cline { 2 - 4 } & No & $19 \%$ & \\
\hline
\end{tabular}

previously reported figures from the same region, which was 39\% [6]. Such decrease in the prevalence might be cognate generally to the rapid change and development of the Arab communities. In additament, during the past few years there has been expeditious amendment in the socioeconomic status of the people in KSA, which has lead to amendment of the living standard of the individual and the community. Hence, decrement of the economic burden on the family and in particular on the husbands, which is reported as one of the main causes for women abuse. Moreover, increment in the caliber of inculcation in particular of woman played a major role in decrementing the chances of women being abused. There have been withal expeditious development of women's rights organizations that availed in incrementing the women's vigilance and offering bulwark.

All types of abuse have marked consequences on the victim. It could affect the victim, physically, psychological as well as their well being or may inflect severe organic complications. It was reported that sexually and physically abused women have $50 \%$ to $70 \%$ increase chances in obtaining gynecological, central nervous system, and or stress-cognate quandaries [13]. Abuse might take many different forms. It could be physical, verbal, emotional, sexual and others. However, in the subsisting study, the majority (74\%) of women were confronted with revilement in comparison to an earlier study in KSA which reported most prevalent type of abuse to be physical [6]. Such change could be considered as an amendment in comportment albeit it is not ethical. It could be expounded by the fact that more women and men are now procuring higher inculcation and being employed, which would deter them from utilizing physical violence. But still being abusive and would use verbal type of mistreating females [14]. It was found that women with higher edifying level are being less abused than the uneducated or women with low inculcation level. That is because such women now incline to ken their rights so they will be more defensive and will not accept any offense against them. Moreover, many women nowadays are financially independent and would not relay on their husbands economically. Hence, are less liable to be abused. These findings are fortified by a study done in Iran which showed that the prevalence of violence against dependent women and who have less than 12 years inculcative level was high [3]. The results additionally showed that the poor economic status and any factor that might lead to it such as job loss, living in a rented house, incremented members of the family are associated with incremented levels of abuse. Economical difficulties put the family under an abundance of pressure and stress, which increases the likelihood of conflict between couples and ultimately abuse. Our findings were consistent with a Sudanese study that affirmed the effect of penuriousness and unemployment to be risk factors for abuse [12]. This may be a controversial subject as other study conducted elsewhere did not link the socioeconomic status with women abuse [7].

In this region and because of male ascendant society still, the community, albeit they are the victims, is optically canvassing many of the abused females negatively. Hence, not a minuscule number of them would not disclose the incidents and therefore would not ask for avail. It was found that only a moiety of the abuse women in the subsisting study have sought help from others to fortify them to stop such act. However, very few would take more vigorous action by reporting the incidence to the police. Several studies have reported homogeneous findings. A study from Egypt reported that a moiety of the studied women would not seek any avail when they were exposed to abuse [8]. Others studies found that the abused incline to consult their primary care physicians twice as more as others, which could be cry for help $[15,16]$. We cerebrate that the high percentage of abused 
women who did not call for avail, they did so because they are either disconcerted, trepidacious or have a credence that such action would affect their espousement and may lead to divorce and disseverment. In integration, due to cultural issues and male ascendant society they may cerebrate that would be perceived by the society as an inferior type of personality. Mass media for community vigilance to break the society's silence about female abuse ought to be implemented [16].

Other risk factors associated with incremented abuse against women were spouse alcohol imbibing as it makes few husbands more truculent and unstable. In additament, history of spouse being abused during their own childhood, which might lead to psychological perturbances in adulthood, was reported to be a peril factor for abuse [12]. Woman who experienced divorce could be more acceptable for being abused in order to evade further divorce. Moreover, women espousing at older age in this component of the world and due to cultural pressure conventionally incline to accept any type of husbands regardless of their edifying, economical or psychological background and this could lead to increment chances of being abused. Hence, not surprisingly a percentage of abused women were found to do accept being abused. This could be due to the culture influences in particular to those women who emanate from rural areas or have old traditions, which enforce them to accept abuse and consider it as a mundane demeanor. Such posture would with no doubt affect the true prevalence of women abuse in the developing countries and make us believe that the reported figures are markedly underestimated. This was pellucid as well in our study when only $19 \%$ admitted abuse while in authenticity they are more.

On the other hand, we found that consanguinity is not cognate to abuse. This finding could be explicated that both sides relatives and because of their blood relationship incline conventionally to play in any conflict as mitigators availing to solve quandaries that may arise between the couple.

\section{Conclusion and Recommendations}

Female abuse is an earnest obnubilated quandary, which is markedly underestimated. Since it has health, gregarious, and psychological consequences on the victim and on the family dynamic, it is recommended fighting such eccentric comportment. Hence, intensive mass media and community vigilance programs aiming at edifying current and future couples should be initiated in order to eschew this quandary. Such programs should commence as early enough probably targeting adolescents especially girls at their school. Women organizations that care about victims of domestic violence against women offering their avail to them should be enheartened to work independently and fortified.

\section{References}

1. http://www.cdc.gov/ViolencePrevention/intimatepartnerviolence/ index.html.

2. http://www.who.int/mediacentre/factsheets/fs239/ar/.

3. Mohammadhosseini E, Sahraean L, Bahrami T (2010) Domestic abuse before, during and after pregnancy in Jahrom, Islamic Republic of Iran. East Mediterr Health J 16: 752-758.

4. Kendall-Tackett KA (2007) Violence against women and the perinatal period: the impact of lifetime violence and abuse on pregnancy, postpartum, and breastfeeding. Trauma Violence Abuse 8: 344-353.

5. Garcia-Moreno C, Watts C (2011) Violence against women: an urgent public health priority. Bull World Health Organ 89: 2.

6. Guimei M, Fikry FE, Esheiba OM (2012) Patterns of violence against women in three communities in Alexandria, Egypt. MCN Am J Matern Child Nurs 37: 331-338.

7. Afifi ZE, Al-Muhaideb NS, Hadish NF, Ismail FI, Al-Qeamy FM (2011) Domestic violence and its impact on married women's health in Eastern Saudi Arabia. Saudi Med J 32: 612-620.

8. Mamdouh HM, Ismail HM, Kharboush IF, Tawfik MM, El Sharkawy OG, et al. (2012) Prevalence and risk factors for spousal violence among women attending health care centres in Alexandria, Egypt. East Mediterr Health J 18: 1118-1126.

9. del Río Ferres E, Megías JL, Expósito F (2013) Gender-based violence against women with visual and physical disabilities. Psicothema 25 : 67-72.

10. Haj-Yahia MM, Wilson RM, Naqvi SA (2012) Justification, perception of severity and harm, and criminalization of wife abuse in the Palestinian society. J Interpers Violence 27: 1932-1958.

11. Maziak W, Asfar T, Mzayek F, Fouad FM, Kilzieh N (2002) Sociodemographic correlates of psychiatric morbidity among low-income women in Aleppo, Syria. Soc Sci Med 54: 1419-1427.

12. Ahmed AM, Elmardi AE (2005) A study of domestic violence among women attending a medical centre in Sudan. East Mediterr Health J 11: 164-174.

13. Campbell J, Jones AS, Dienemann J, Kub J, Schollenberger J, et al. (2002) Intimate partner violence and physical health consequences. Arch Intern Med 162: 1157-1163.

14. Tashkandi A, Rasheed FP (2009) Wife abuse: a hidden problem. A study among Saudi women attending PHC centres. East Mediterr Health J 15: 1242-1253.

15. Lo Fo Wong S, Wester F, Mol S, Römkens R, Lagro-Janssen T (2007) Utilisation of health care by women who have suffered abuse: a descriptive study on medical records in family practice. Br J Gen Pract 57: 396-400.

16. Usta J, Antoun J, Ambuel B, Khawaja M (2012) Involving the health care system in domestic violence: what women want. Ann Fam Med 10: 213-220. 